\title{
АНАЛИЗ ТЕОРЕТИЧЕСКИХ ВОЗЗРЕНИЙ НА СУЩНОСТЬ, ПРЕДПОСЫЛКИ И ВИДЫ ТОРГОВЛИ ЛЮДЬМИ И ИХ МЕСТО В СМИ Махзуна Алижон қизи БОЗОРОВА
}

Доктор философии по филологическим наукам (PhD)

Старший преподаватель

Университет журналистики и массовых коммуникаций Узбекистана

Ташкент, Узбекистан

\section{ОДАМ САВДОСИ МОХИЯТИ, САБАБЛАРИ ВА ТУРЛАРИГА НАЗАРИЙ ҚАРАШЛАР ТАХЛИЛИ ВА УЛАРНИНГ ОАВДА ЎРНИ \\ Махзуна Алижон қизи БОЗОРОВА \\ Филология фанлари доктори (PhD) \\ Катта ўқитувчи \\ Ўзбекистон журналистика ва оммавий коммуникациялар университети \\ Тошкент, Ўзбекистон}

\author{
ANALYSIS OF THEORETICAL VIEWS OF THE ESSENCE, BACKGROUND AND \\ TYPES OF HUMAN TRAFFICKING AND THEIR PLACE IN THE MEDIA \\ Makhzuna Alijon qizi BOZOROVA \\ Doctor of Philosophy in Philological Sciences (PhD) \\ Senior Lecturer \\ University of Journalism and Mass Communications of Uzbekistan \\ Tashkent, Uzbekistan mahzuna.bozorova@gmail.com
}

UDC (УўК, УДК): 004.1:05/07

For citation (иқтибос келтириш учун, для цитирования): Бозорова М.А. Анализ теоретических воззрений на сущность, предпосылки и виды торговли людьми и их место в СМИ// Ўзбекистонда хорижий тиллар. — 2021. — № 6 (41). — С.202-214.

\section{https://doi.org/10.36078/1644602825}

Received: October 25., 2021

Accepted: December 17, 2021

Published: December 20, 2021

Copyright () 2021 by author(s) and Scientific Research Publishing Inc.

This work is licensed under the Creative Commons Attribution International License (CC BY 4.0).

http://creativecommons.org/licenses/by/4.0/ Open Access

\begin{abstract}
Аннотация. В данной статье рассматриваются подходы ученых различных стран, в том числе и узбекистанских, к дефиниции «торговля людьми», факторам, способствующим еe распространению, а также к ее классификации. Цель работы заключается в изучении на основе сравнительного анализа теоретических воззрений исследователей в данной области, выявлении оптимальных формулировок для их применения в деятельности средств массовой информации. При обобщении взглядов ученых по данному вопросу нами предложена трактовка термина «торговля людьми», применимая к деятельности медиа. Кроме того, на основе анализа различных взглядов на разновидности торговли людьми выбрана классификация российского исследователя Я.В. Ванюшовой, учитывающая практически все аспекты данного явления. Данная работа важна тем, что она сможет стать источником базовых знаний в практической деятельности журналистов, намеренных подготовить материал на тему траффикинга. Научная новизна статьи состоит в том, что в ней установлено, что в отечественных и зарубежных исследованиях до сих пор не разработано исчерпывающее описание дефиниции «торговля людьми», впервые теоретически обоснована трактовка термина
\end{abstract} применительно к деятельности СМИ. 
Ключевые слова: торговля людьми; траффикинг; жертва; СМИ; факторы; классификация; виды; противодействие торговле людьми.

Аннотация. Ушбу мақолада турли мамлакатлар, жумладан, ўзбекистонлик олимларининг “одам савдоси” таърифи, унинг тарқалишига таъсир этувчи омиллар, шунингдек, таснифлашга бўлган ёндашувлари кўриб чиқилади. Ишнинг мақсади қиёсий тахлил асосида тадқиқотчиларнинг ушбу йўналишдаги назарий қарашларини ўрганиш, уларни оммавий ахборот воситалари фаолиятида кўлланилиши маъқул бўлган таърифларни аниқлашдан иборат. Бу борада олимларнинг илмий асосланган фикрларини умумлаштирган холда, биз оммавий ахборот воситалари фаолиятига тааллуқли “одам савдоси” атамасининг талқинини таклиф қилдик. Бундан ташқари, одам савдосининг турлари бўйича турли қарашларни тахлил қилиш асосида биз россиялик тадқиқотчи Я.В. Ванюшованинг таснифини танладик. Унда одам савдосининг деярли барча жихатлари хисобга олинган. Бу иш одам савдоси мавзусида материал тайёрлаш ниятида бўлган журналистларнинг амалий фаолиятида бирламчи билим манбаи бўлиши мумкинлиги билан хам ахамиятлидир. Мақоланинг илмий янгилиги шундаки, унда махаллий ва хорижий тадқиқотларда ханузгача “одам савдоси" таърифининг тўлиқ тавсифи ишлаб чиқилмаганлиги аниқланган, илк маротаба ушбу атаманинг ОАВ фаолиятига мос талқини назарий жихатдан асосланган.

Калит сўзлар: одам савдоси; траффикинг; курбонлар; ОАВ; классификация; турлар; одам савдосига қарши кураш

Abstract. This article discusses the approaches of scientists from various countries, including those from Uzbekistan, to the definition of "human trafficking", the factors contributing to its spread, and its classification. The purpose of the work is to study, based on comparative analysis, the theoretical views of researchers in this field to identify the optimal formulations for their application in the activities of the media. Summarizing the scientifically based opinions of the scientists on this issue, we have proposed an interpretation of the term "human trafficking", applicable to the activities of the media. In addition, based on the analysis of different views on the types of human trafficking, we have chosen the classification of the Russian researcher Ya.V. Vanyushova, who considers almost all aspects of this phenomenon. This work is important because it can become a source of basic knowledge in the practical activities of journalists who intend to prepare material on human trafficking. The scientific novelty of the article lies in the fact that it establishes that domestic and foreign studies have not yet developed a detailed description of the definition of "human trafficking". The interpretation of the term in relation to the activities of the media has been theoretically substantiated.

Keywords: human trafficking; victim; media; classification; types; combating human trafficking. 
Торговля людьми, выступая сложным видом преступной деятельности, имеет серьёзные психологические, духовнонравственные, физические последствия и сказывается в постэксплуатационной жизни жертвы, что напрямую отражается на темпах реабилитации пострадавшего.

Ввиду того что невозможно определить точное количество рабов в современном мире, официальные источники представляют разные цифры. Как сообщается в отчете «The Global Slavery Index»» ${ }^{1}$ за 2018 год, «сегодня в руках работорговцев находятся 40 миллионов 300 тысяч человек» (25). В отчете $\mathrm{OOH}$ за 2018 год указано, что «количество пострадавших в 2016 году составляет 25 тысяч 400 человек, что на $40 \%$ больше по сравнению с 2011 годом» $(24,23)$.

Основная часть. Увеличению числа жертв есть ряд причин и факторов правового, социально-экономического, морального характера.

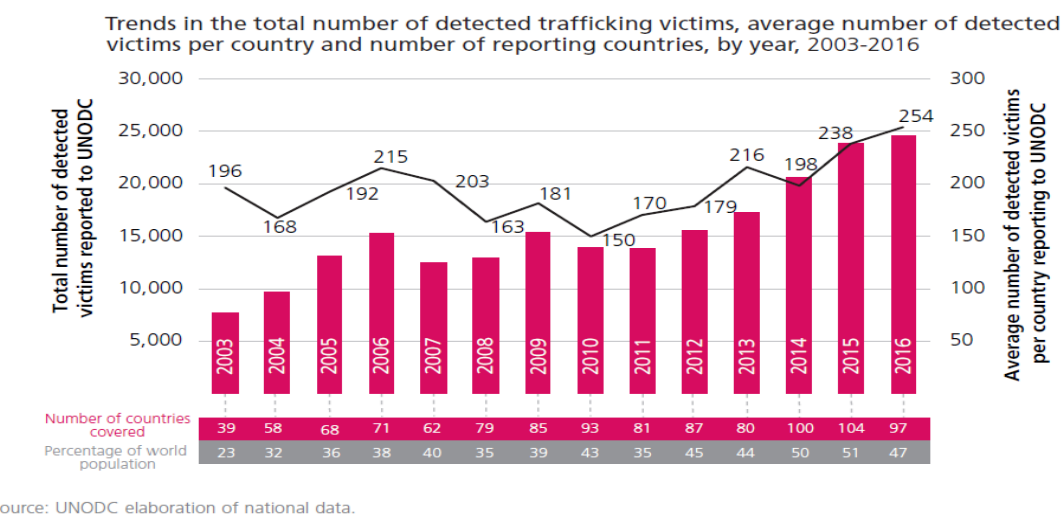

Рисунок 1. Тенденция общего количества обнаруженных жертв торговли людьми, среднее число жертв на страну и количество стран, предоставляющих отчеты, за 2003-2016

Исследователи торговли людьми по этому поводу выдвигают самые разные обоснования.

Так, с позиции Ф.Н. Кадникова, основными факторами, «детерминирующими данный вид преступления являются экономическая интеграция и ... процесс глобализации, активизация транснациональной организованной преступности, мировая трудовая миграция, коррупция в органах государственной власти, недостаточный уровень профессионализма органов правопорядка, развитие индустрии секса, безработица, проблемы законодательства и т.д.» $(9,13-14)$. Такого же мнения придерживаются Д. Н. Кожухарик, П. Т. Савин $(10,64-67)$.

С точки зрения А. Н. Тукубашевой, причинами увеличения количества жертв торговли людьми «являются бедность населения, теневая экономика и коррупция, миграция населения, дискриминация

${ }^{1}$ Данный индекс предоставляет предполагаемую карту 167 стран мира о масштабах распространенности торговли людьми, а также информацию о мерах, предпринятых правительствами стран по противодействию данному явлению. 
по признаку пола» (8, 119). В противовес данному мнению А. В. Матвиенко считает, что «существуют некоторые расхождения между уровнем бедности и количеством жертв торговли людьми в отдельно взятых странах» $(13,58)$. Однако исследователи полагают, что даже самые бедные страны не всегда выступают в качестве основных поставщиков «живого» товара. Сам факт отсутствия денег, либо средств к существованию не может быть рассмотрен в качестве причины распространения торговли людьми. Кроме того, даже если безработица и усиливает социальную напряженность, порождает бедность, толкает людей на поиски работы в других регионах и странах, она как обособленный фактор рассматриваться не может, поскольку торговля людьми представляет собой «сложный механизм, в основе которого лежит целый причинный комплекс» $(13,68)$.

Итоги социального опроса, проведенного узбекистанским ученым И. Ю. Фазиловым, показывают, что «основными причинами торговли людьми на локальном уровне служат недостаточное обеспечение занятости населения, сильное желание людей трудоустроиться и разбогатеть легким путем, низкая правовая грамотность и др.» $(23,330-331)$. Зарубежный исследователь Гету Маконен отмечает тот факт, что «бедность и информированность людей взаимосвязаны между собой, определяют степень грамотности населения〉 $(27,142-156)$.

Обобщая все эти точки зрения, следует отметить, что торговля людьми связана с проблемой латентизации ${ }^{2}(21)$, обусловленной целой системой факторов, наиболее важными из которых являются:

1) правовые: сложности толкования термина, коррупция, низкий уровень правовой грамотности населения;

2) экономические: экономическое неравенство стран в условиях глобализации, несоответствующий уровень жизни населения, безработица;

3) морально-этические: исчезновение национальной идентичности народов, пропаганда свободных сексуальных отношений и др. $(15,744-745)$.

Между тем существуют трудности и расхождение мнений при толковании исследователями самого термина «торговля людьми», что напрямую порождает путаницу как среди журналистов, так и массовой аудитории. Изначально отметим, что наш анализ определений данного термина, зафиксированных в правовых документах, осуществлен, прежде всего, применительно к нашему объекту исследования — к печатным СМИ.

Торговля людьми имеет схожие признаки с рабством ${ }^{3}(32,501)$, ввиду этого ее называют «современным рабством». Однако в отличие от рабства торговля людьми противозаконна и совершается против воли жертвы.

По версии ООН, зафиксированной в Протоколе о предупреждении и пресечении торговли людьми, особенно женщинами и детьми, и наказании за неё, дополняющем Конвенцию

2 Латентизация - это реализующаяся латентность, при которой результатом является объективация «неизвестности» преступного посягательства. Латентность преступлений - это потенциальная возможность быть скрытым.

${ }^{3}$ Рабство - это деятельность, в процессе которой одни люди управляют другими. Раб - это собственность владельца и работает без вознаграждения за свой труд. Но владелец обеспечивает подчиняемого едой, жильём и одеждой. 
против транснациональной организованной преступности, под торговлей людьми понимается «вербовка, перевозка, передача, укрывательство или получение людей путем угрозы, силой или ее применения или других форм принуждения, похищения, мошенничества, обмана, злоупотребления властью или уязвимостью положения, либо путем подкупа в виде платежей или выгод для получения согласия лица, контролирующего другое лицо» (17).

Как указывается в статье «What is human trafficking?» (30, 10151019), в данной дефиниции определяющими признаками торговли людьми являются, «во-первых, перевозка человека, во-вторых, сила, мошенничество или принуждение и, наконец, эксплуатация». По нашему мнению, перевозка человека является дополняющим элементом ввиду того, что данное преступное деяние вполне может осуществляться и в рамках одного государства. Кроме того, сила, угроза и др. - это и есть формы принуждения (28). Значит, перечисленные методы воздействия на жертву необходимо заменить физическими и психологическими формами принуждения. Ввиду этого, на наш взгляд, детерминирующими составляющими траффикинга являются вербовка (независимо обманным или другим путем вовлекается жертва), если жертва продается другому покупателю - передача жертвы, если не продается - принуждение жертвы к выполнению указов эксплуататоров, используя его любые формы, и эксплуатация.

Учёные всего мира ведут споры по корректности данной дефиниции. В частности, российский исследователь М. Ю. Буряк полагает, что такая «трактовка страдает избыточной громоздкостью и перегружено лишними деталями, в частности, перечислением способов воздействия на жертву. Кроме того, ... в нем отсутствует упоминание психологического воздействия, шантажа и тому подобного» $(2,26)$. В целом, соглашаясь с ученым, добавим, что данная формулировка не предназначена для аудитории СМИ, поскольку в описании технологии торговли людьми наблюдается некоторый диссонанс, что приводит к дезориентации читателя. Кроме того, психологическое воздействие и шантаж исследователь рассматривает по отдельности. Как считает кризисный психолог М. Пиянова, «в формах принуждения как одного из видов психологического влияния могут использоваться угрозы, шантаж, лишение свободы» (14). Иначе говоря, шантаж - это вид психологического воздействия.

Б. Б. Ахмедов считает, что «только купля-продажа человека является торговлей людьми в собственном смысле этого понятия. Остальные же действия (вербовка, перевозка, передача, укрывательство и получение) лишь содействуют или сопутствуют купле-продаже человека» $(1,155)$. Между тем траффикинг не ограничивается рамками только договора купли-продажи. К тому же при задержании подозреваемых в совершении торговли людьми их вина может быть не доказана, если купля-продажа не была осуществлена, однако при этом очевидны другие действия преступления (вербовка, принуждение и др.). В силу чего отождествление понятий «торговля людьми» и «купля-продажа» явно недопустимо.

Франк Лацко и Марко Грамегна замечают, что «...определение [OOH] более точное, чем предыдущие, но, несмотря на это, ряд комментаторов указывают на сохраняющуюся сложность измерения торговли людьми, учитывая диапазон действий и результатов, охватываемых этим термином» (26). Точнее, существует огромное 
разнообразие систем торговли людьми и взаимосвязей внутри них. И данные факторы затрудняют сбор данных о торговле людьми.

Участники проекта Human Trafficking Search ${ }^{4}$ под траффикингом понимают «незаконную куплю-продажу людьми путем похищения, использования угрозы силы, обмана, мошенничества или «продажу» в целях сексуальной эксплуатации и принудительного труда» $(31,15)$. Недостатком данной трактовки является то, что формы, виды торговли людьми, а также методы манипуляции жертвой намного шире, чем указано в данном определении.

Эксперты Всемирного Альянса против торговли женщинами ${ }^{5}$ полагают, что торговля людьми представляет собой «совокупность действий, связанных с вербовкой, перевозкой в пределах одной или нескольких стран, куплей, продажей, перемещением, передачей из рук в руки или удержанием лица или группы лиц: а) обманным путем, принуждением лица (включая применение насилия или угрозу его применения или злоупотребление служебным положением) или вовлечением этого лица в долговую кабалу; б) с целью удержания этого лица за плату или без таковой в подневольном состоянии или в условиях, подобных рабству» $(19,9)$. На наш взгляд, во-первых, торговля людьми не ограничивается рамками названных действий, вовторых, преступная деятельность может рассматриваться как отдельно взятые действия, а не в совокупности. Кроме того, данное определение не содержит основную цель преступного деяния: эксплуатация жертвы в целях получения прибыли.

Здесь и в других вышеприведенных определениях в основном подразумеваются два вида траффикинга: сексуальная и трудовая эксплуатация. Однако существуют и иные его формы, носящие единичный характер действия. К примеру, торговля детьми, изъятие органов и тканей, принуждение молодых девушек к браку и другие. Они имеют иную технологию преступности и потому нуждаются в научном осмыслении на глобальном уровне.

По Стивену Галстеру, составляющими торговли людьми выступают «использование обмана, принуждение (включая применение силы, или её угрозу, или злоупотребление властью), долговая зависимость или все вышеперечисленное» $(11,14)$. Эти элементы являются средствами, способами воздействия на жертву, но не образовывают состав самого преступного деяния.

Наиболее оптимальный вариант определения «торговля людьми», на наш взгляд, содержится в Уголовном Кодексе РУз: «купля-продажа человека либо его вербовка, перевозка, передача, укрывательство или получение в целях его эксплуатации» (22). В этом лаконичном определении суть преступного деяния обозначена предельно ясно: хронология действий и цели торговли. Однако для полноценного раскрытия содержания термина «торговля людьми» считаем целесообразным дополнить данную трактовку еще тремя элементами, предложенными NHTH (Национальной горячей линией по борьбе с торговлей людьми США): сила, мошенничество и принуждение (29). Специалисты данного проекта разработали модель

${ }^{4}$ Human Trafficking Search - основной проект O.L. Pathy Family Foundation, частный фонд, который стремится продвигать креативные и инновационные решения против торговли людьми и искоренить проблемы травматизма, бедности и неравенства.

5 GAATW объединяет 80 неправительственных организаций из Африки, Азии, Европы, стран Латинской Америки и Северной Америки. 
«Действие - Средства - Цель», которая может быть использована для описания элементов торговли людьми и их классификации (29). Узбекистанские исследователи И. Ю. Фазилов и М. Х. Рустамбоев также предлагают свои трактовки. Так, И. Ю. Фазилов полагает, что «торговля людьми - это осуществление противозаконного договора по отношению к человеку или вербовка, перевозка, передача, получение, укрывательство или удержание человека в целях его эксплуатации» ${ }^{6}(23,329)$. На наш взгляд, данное определение, во-первых, проигрывает за счёт отсутствия указания в нём средств достижения целей торговцев людьми. Во-вторых, зафиксированное в нем понятие «протиправный договор по отношению к человеку» очень широко по содержанию и может подразумевать все деяния вплоть до умышленного убийства.

М. Х. Рустамбоев считает, что «торговля людьми - это купляпродажа, то есть переход человека в собственность покупателя за счёт денег или другого имущественного эквивалента (движимость и недвижимость, имущественная выгода, прощение имущественного или денежного долгов), переданного продавцу» $(18,12)$. В противовес мнению И. Ю. Фазилова данная трактовка, на наш взгляд, узка для описания феномена торговли людьми, так как предусматривает только куплю-продажу. Как подчеркивается в Гражданском Кодексе РУз, «по договору купли-продажи одна сторона (продавец) обязуется передать товар в собственность другой стороне (покупателю), а покупатель обязуется принять этот товар и уплатить за него определенную денежную сумму (цену)» (5). А алгоритм процесса торговли людьми более сложный и многофункциональный.

По поводу таких трактовок отечественных исследователей Н. Б. Курбонов в своей диссертации отмечает, что «...учёные упускают из виду тот факт, что целью купли жертв является их эксплуатация в различных целях и использование человеческих органов» $(12,24)$.

Многополярные подходы к сущности торговли людьми наблюдаются и среди российских ученых. Например, определение Е. В. Евстифеевой ${ }^{7}(7,95)$ преобладает очевидными достоинствами. Однако, по мнению М. Ю. Буряк, оно несовершенно и автор безосновательно исключает из круга преступных деяний рекомендуемые к криминализации Протоколом 2000 года действия в отношении человека. В дефиниции не содержатся и упоминания одной из главных целей торговли - иные разновидности эксплуатации, кроме трудовой $(2,28-29)$. Вдобавок за счёт обилия определений (чаще качественных прилагательных, например, общественно опасный, корыстный. - Прим. автора) повышается уровень субъективизма, а изложение теряет свою научность и официальность. Кроме того, двукратное использование слова «иной» требует дополнительных разъяснений.

${ }^{6}$ Одам савдоси - одамга нисбатан қонунга хилоф битимни амалга ошириш ёхуд одамни эксплуатация қилиш мақсадида ёллаш, ташиш, топшириш, қабул қилиш, яшириш ёки ушлаб туриш.

7 Торговля людьми определяется как совокупность общественно опасных деяний, посягающих на личную свободу человека, выражающиеся в совершении сделок в отношении человека, обращении в рабство, принуждении к труду, сопряженные с применением физического или психического насилия, обмана, шантажа, использованием материальной или иной зависимости потерпевшего и иными способами в целях использования этих лиц для корыстных или иных побуждений. 
А. В. Матвиенко считает, что торговля людьми есть «вербовка, перевозка, передача, получение или укрывательство лица, осуществляемые в целях его последующей эксплуатации» $(13,31)$. Крымский исследователь Т. Г. Данько (6, 855-861) придерживается такого же мнения, что и А. В. Матвиенко. На наш взгляд, именно это определение, компактное и понятное по содержанию, отвечает требованиям доступности и ясности для передачи информации целевой аудитории.

С учётом вышесказанного предлагаем свое определение термина: под торговлей людьми следует понимать куплю-продажу и/или вербовку, перевозку, передачу, укрывательство, получение человека в целях его эксплуатации путем применения силы, обмана и/или принуждения для извлечения финансовой выгоды. Полагаем, что такое определение научно обоснованно и полностью соответствует международному законодательству, а также вносит ясность в научные дискуссии о сущности торговли людьми.

Существуют различные виды торговли людьми. В этом смысле, Е. В. Тюрюканова и М. М. Малышева выделяют следующие ее разновидности: «принудительный труд, в том числе в «потогонном производстве» (нелегальном или теневом, преступном); секс-торговля; домашнее рабство; браки по принуждению, в том числе через систему «невест по почте»; принудительное использование репродуктивных функций, включая рождение и воспитание ребенка; принудительное донорство (продажа людей для трансплантации органов и тканей); принудительное усыновление/удочерение» $(20,97)$. Ввиду того что в данной классификации отсутствуют такие разновидности траффикинга, как торговля детьми, в частности использование детей в вооруженных целях, для попрошайничества и производства детской порнографии и др., она не является исчерпывающей.

Рабочая группа $\mathrm{OOH}$ по современным формам рабства составила свой перечень маркированных траффикингом нарушений прав человека. В него входят: «купля-продажа детей; детская проституция; детская порнография; детский труд; сексуальный туризм; использование детей в вооруженных силах; эксплуатация трудящихсямигрантов; незаконное усыновление; торговля людьми; торговля органами человека; эксплуатация проституции других лиц; насилие в отношении женщин; принуждение к вступлению в брак; долговая кабала; принудительный труд» $(4,175)$. Данный список, во-первых, неполный. А во-вторых, страдает неточностью, в нем смешаны цель торговли людьми с ее формой: к примеру, принудительный труд и эксплуатация трудящихся-мигрантов.

На наш взгляд, наиболее полный перечень видов траффикинга представлен Я.В. Ванюшовой. Это:

1. «Торговля людьми, особенно женщинами и детьми, с целью сексуальной эксплуатации: в сфере развлечений и секс-индустрии; в организованной секс-торговле в местах расположения войск; в организации секс-туризма; в производстве порнографии. 2. Торговля людьми в целях эксплуатации рабского труда: в «потогонном производстве» ${ }^{8}(16) ;$ в неформальной и теневой экономике; при производстве контрафактной продукции ${ }^{9}$; в домашнем хозяйстве

${ }^{8}$ Потогонная система - форма производства, допускающая самую крайнюю эксплуатацию трудящегося.

9 Термином «контрафакт» обозначают любой товар, изготовленный с нарушением прав интеллектуальной собственности какого-либо лица. 
(домашнее рабство); детский труд (мытье машин, работа в сельском хозяйстве и т.п.) и др. 3. Торговля людьми, особенно детьми и инвалидами с целью попрошайничества: использование детей; использование инвалидов; «аренда» младенцев для попрошайничества. 4. Браки в целях эксплуатации (включая использование системы «невест по почте»): для использования человека в домашнем хозяйстве (домработницы и т.п.); для принудительного вынашивания и рождения детей; для обслуживания больных и престарелых родственников, детей и др. 5. Торговля людьми с целью принуждения к суррогатному материнству, репродуктивным функциям. 6. Торговля людьми для принудительной трансплантации органов и тканей. 7. Торговля детьми с целью принудительного усыновления/удочерения. 8. Торговля людьми с целью использования в вооруженных формированиях. 9. Использование солдат для принудительных работ» $(3,150)$.

Следует иметь ввиду, что данная преступная деятельность активно развивается и ее участники гибко приспосабливаются к мерам, принимаемым против них, к переменам на политической и социальноэкономической арене глобального и локального характера. В силу этого появление новых или гибридных форм траффикинга обретает непрерывный характер. А значит, вопрос классификации видов траффикинга остается открытым.

Заключение. Таким образом, теоретические дискуссии по сущности дефиниции «торговля людьми», её предпосылок и классификации велись, в основном, в юридическом аспекте. Определению «торговля людьми» наиболее широкое толкование дано в юриспруденции, что содействовало и пониманию сущности термина «современное рабство». Обобщая теоретические воззрения по данному вопросу, нами предложена трактовка термина «торговля людьми», применимая к деятельности СМИ. Под торговлей людьми, на наш взгляд, следует понимать куплю-продажу и/или вербовку, перевозку, передачу, укрывательство, получение человека в целях его эксплуатации путем применения силы, обмана и/или принуждения для извлечения финансовой выгоды. Такое определение полностью соответствует международному законодательству. Кроме того, на основе анализа различных взглядов на виды торговли людьми нами выбрана классификация Я.В. Ванюшовой, учитывающая практически все аспекты данного явления.

\section{Использованная литература}

1. Ахмедов Б.Б. Торговля людьми: проблемы противодействия // Вестник Омского университета. Серия Право. — 2008. — № 2 (15). C. $155-159$.

2. Буряк М.Ю. Торговля людьми и борьба с ней: криминологические и уголовно-правовые аспекты: диссертация ... канд. юр. н.: 12.00.08. Владивосток: Юридический ун-т ДВГУ, 2005. — 246 с.

3. Ванюшова Я.В. Торговля людьми как социально-правовое явление // Проблемы статуса современной России: историко-правовой аспект: Сборник статей Всероссийской научно-практической конференции. Уфа, 2018. - С. 145-153.

4. Гасанов Р.Т. Борьба с торговлей людьми в Совете Европы и законодательстве Азербайджанской Республики // Право и Общество. - 2011. — № 8 (030). - C. 154-182. 
5. Гражданский Кодекс Республики Узбекистан. Часть 2. Подраздел 3. Отдельные виды обязательств. Глава 29. Купля-продажа. § 1. Общие положения о купле-продаже. Статья 386. Утвержден Законами РУз от 21.12.1995 и от 29.08.1996 г. // http://www.lex.uz/acts/180550 [дата обращения: 13.03.2019].

6. Данько Т.Г. Торговля людьми как проблема мирового правопорядка // Современные тенденции развития права в условиях глобализации: сравнительно-правовой аспект/ Материалы III Всероссийской научно-практической конференции с международным участием профессорско-преподавательского состава, аспирантов и студентов. Симферополь, 19-20 апреля 2018 года. Издательство: Крымский федеральный университет им. В.И. Вернадского (Симферополь). - С. 855-861.

7. Евстифеева Е.В. Теоретические проблемы уголовно-правовой ответственности за торговлю людьми: дисс...канд.юр.наук: 12.00.08. - Саратов: Саратовская государственная академия права, 2002. - 197 c.

8. Исаева К.А., Салиев А.А. К вопросу об основных факторах, детерминирующих торговлю людьми, с участием организованных преступных групп // Международный журнал экспериментального образования. - 2017. - № 6. - C. 118-121; URL: https://expeducation.ru/ru/article/view?id=11706

9. Кадников Ф.Н. Криминологическая характеристика и предупреждение преступлений, связанных с торговлей людьми: дисс. ... канд. юрид. наук: 12.00.08. - М.: Московский университет МВД России, 2007. - 243 с.

10. Кожухарик Д.Н., Савин П.Т. Проблемы международной борьбы с торговлей людьми // Расследование преступлений: проблемы и их пути решения. — 2018. — № 1 (19). — С. 64-67.

11. Колдуэлл Г., Галстер С., Стейнзор Н. Преступление и порабощение. Разоблачение секс-торговли женщинами из стран бывшего СССР.: доклад, представленный на конференции «Проблема вывоза женщин из СНГ для сексторговли за рубежом» (М., 1997). Вашингтон: Global Survival Network, 1997.

12. Курбонов Н.Б. Одамлардан фойдаланиш учун ёллаш жиноятида жавобгарлик масалалари (жиноят хукуқий ва криминологик жихатлари): юр.ф.н.дисс., 12.00.08. — Т: ТДЮИ, 2011. - 180 б.

13. Матвиенко А.В. Региональные социально-экономические аспекты торговли людьми в современном мире: диссертация ... канд. геогр. н.: 25.00.24. — Краснодар: Кубан. гос. ун-т, 2011. — 180 с.

14. Основные виды психологического воздействия и влияния // https://psyhoday.ru/obshchenie/vidy-psihologicheskogovliyaniya.html\#h3_11 [дата обращения: 17.03.2019].

15. Ополовникова Д.М. Торговля людьми: состояние проблемы (отдельные криминологические аспекты) // Традиции и новации в системе современного российского права. Сборник тезисов XVII Международной научно-практической конференции молодых ученых, Москва, 2018. - С. 744-745.

16. Потогонная система // https://ru.wikipedia.org/wiki/\%D0\%9F\%D0\%BE\%D1\%82\%D0\%BE\%D0 $\% \mathrm{~B} 3 \% \mathrm{D} 0 \% \mathrm{BE} \% \mathrm{D} 0 \% \mathrm{BD} \% \mathrm{D} 0 \% \mathrm{BD} \% \mathrm{D} 0 \% \mathrm{~B} 0 \% \mathrm{D} 1 \% 8 \mathrm{~F} \% \mathrm{D} 1 \% 81 \% \mathrm{D} 0 \%$ B8\%D1\%81\%D1\%82\%D0\%B5\%D0\%BC\%D0\%B0 [дата обращения: 26.03.2019].

17. Предупреждение и пресечение торговли людьми, особенно женщинами и детьми, и наказание за нее. Протокол, дополняющий 
Конвенцию оОо оровив трансациональной организованной преступности. Принят 15 ноября 2000 года // http://www.un.org/ru/documents/decl_conv/conventions/protocol1.shtml [дата обращения: 03.03.2019].

18. Рустамбоев М.Х. Одам савдоси. - Тошкент: ТДЮИ, 2009. - 316 6.

19. Стандартные правозащитные принципы обращения с лицами, пострадавшим от торговли людьми. Под ред. Ф.Л. Синицына. Пермь: ИД «Типография купца Тарасова», 2002. - 32 с.

20. Тюрюканова Е.В., Малышева М.M. Женщина. Миграция. Государство. - М.: Academia, 2001. - 229 с.

21. Уваров А.И. Латентность пенитенциарной преступности: понятие и виды // Гуманитарные, социально-экономические и общественные науки. - 2016. — № 5. - С. 132-136.

22. Уголовный Кодекс Республики Узбекистан. Введен в действие с 01.04.1995 г. // http://www.lex.uz/acts/111457 [дата обращения: 3.03.2019].

23. Фазилов И.Ю. Одам савдосига қарши курашнинг жиноят-хуқуқий ва криминологик жихатлари: юр.ф.д.дисс., 12.00.08. - Т: ЎзР ИИВ Академияси, 2016. - 379 б.

24. Global Report on Trafficking in Persons 2018. — Vienna: UNODC, 2018. - 90 p.

25. Global Slavery Index // https://www.youtube.com/watch?v=CcJGsqCaaKo [дата обращения: 09.03.2019].

26. Laczko F., Marco A. Gramegna. Developing Better Indicators of Human Trafficking // The Brown Journal of World Affairs. - 2003. - Vol. 10. - No. 1. - P. 179-194.

27. Makonen G. Human Trafficking and Development: The Role of Microfinance // Transformation. - 2006. - Vol. 23. - No. 3, P. 142-156. 28. Merriam-Webster. Coerce is to achieve by force or threat // https://www.merriam-webster.com/dictionary/coercing [дата обращения: 16.03.2019].

29. National Human Trafficking hotline // https:/humantraffickinghotline.org/mission/ [дата обращения: 19.03.2019].

30. Salazar R.P., Cecilia M.H., Ruth H.L. What Is Human Trafficking? // Sex: A Thematic Issue. The University of Chicago Press. - 2012. - Vol. 37. - No. 4. - PP. 1015-1029.

31. Salett E., Nasr F. Glossary and definitions. Human Trafficking Search, 2017. - 26 p.

32. The World Book Encyclopedia. Volume 17. — USA: World Book Inc. $-446 \mathrm{p}$.

\section{References}

1. Akhmedov B.B., Vestnik Omskogo universiteta, ser. Pravo, 2008, No. 2 (15), pp. 155-159.

2. Buryak M.Yu., Torgovlya lyud'mi i bor'ba s nei: kriminologicheskie $i$ ugolovno-pravovye aspekty (Human trafficking and combating it: criminological and criminal law aspects), candidate's thesis, Vladivostok: Yuridicheskii un-t DVGU, 2005, 246 p.

3. Vanyushova Ya.V., Problemy statusa sovremennoi Rossii: istorikopravovoi aspekt: Sbornik statei Vserossiiskoi nauchno-prakticheskoi konferentsii, Ufa, 2018, pp. 145-153.

4. Gasanov R.T., Pravo i Obshchestvo, 2011, No. 8 (030), pp. 154-182. 
5. http://www.lex.uz/acts/180550 [data obrashcheniya: 13.03.2019].

6. Dan'ko T.G., Sovremennye tendentsii razvitiya prava $v$ usloviyakh globalizatsii: sravnitel'no-pravovoi aspekt, 2018, pp. 855-861.

7. Evstifeeva E.V., Teoreticheskie problemy ugolovno-pravovoi otvetstvennosti za torgovlyu lyud'mi (Theoretical problems of criminal liability for human trafficking), candidate's thesis, Saratov: Saratovskaya gosudarstvennaya akademiya prava, 2002, $197 \mathrm{p}$.

8. Isaeva K.A., Saliev A.A., International journal of experimental education, Legal Sciences, 2017, No. 6, pp. 118-121.

9. Kadnikov F.N., Kriminologicheskaya kharakteristika i preduprezhdenie prestuplenii, svyazannykh s torgovlei lyud'mi (Criminological characteristics and prevention of crimes related to human trafficking), candidate's thesis, Moscow: Moskovskii universitet MVD Rossii, 2007, 243 p.

10. Kozhukharik D.N., Savin P.T., Rassledovanie prestuplenii: problemy $i$ ikh puti resheniya, 2018, No. 1 (19), pp. 64-67.

11. Kolduell G., Galster S., Steinzor N., Problema vyvoza zhenshchin iz SNG dlya sekstorgovli za rubezhom, Washington, Global Survival Network, 1997.

12. Kurbonov N.B., Odamlardan foidalanish uchun ellash zhinoyatida zhavobgarlik masalalari (zhinoyat x̧иқ̧иқii va kriminologik zhix̧atlari (Issues of responsibility in the crime of recruitment for use of people (criminal and criminological aspects), candidate's thesis, Tashkent: TDYuI, 2011, $180 \mathrm{p}$.

13. Matvienko A.V., Regional'nye sotsial'no-ekonomicheskie aspekty torgovli lyud'mi v sovremennom mire (Regional socio-economic aspects of human trafficking in the modern world), candidate's thesis, Krasnodar: Kuban. gos. un-t, 2011, $180 \mathrm{p}$.

14. https://psyhoday.ru/obshchenie/vidy-psihologicheskogo-

vliyaniya.html\#h3_11.

15. Opolovnikova D.M. Traditsii $i$ novatsii $v$ sisteme sovremennogo rossiiskogo prava. Sbornik tezisov XVII Mezhdunarodnoi nauchnoprakticheskoi konferentsii molodykh uchenykh, Moscow, 2018, pp. 744-745. 16. https://ru.wikipedia.org/wiki/\%D0\%9F\%D0\%BE\%D1\%82\%D0\%BE\% D0\%B3\%D0\%BE\%D0\%BD\%D0\%BD\%D0\%B0\%D1\%8F_\%D1\%81\%D 0\%B8\%D1\%81\%D1\%82\%D0\%B5\%D0\%BC\%D0\%B0.

17. $\mathrm{ml}$.

http://www.un.org/ru/documents/decl_conv/conventions/protocol1.sht

18. Rustamboev M.Kh., Odam savdosi (Human trafficking), Tashkent: TDYuI, 2009, $316 \mathrm{p}$.

19. Standartnye pravozashchitnye printsipy obrashcheniya s litsami, postradavshim ot torgovli lyud'mi (Human Rights Standard Principles for the Treatment of Victims of Human Trafficking). Perm': ID “Tipografiya kuptsa Tarasova", 2002, $32 \mathrm{p}$.

20. Tyuryukanova E.V., Malysheva M.M., Zhenshchina. Migratsiya. Gosudarstvo (Women. Migration. State), Moscow: Academia, 2001, 229 p. 21. Uvarov A.I., Gumanitarnye, sotsial'no-ekonomicheskie $i$ obshchestvennye nauki, 2016, No. 5, pp. 132-136.

22. http://www.lex.uz/acts/111457.

23. Fazilov I.Yu., Odam savdosiga ķarshi kurashning zhinoyat-x̧иқ̧иқ̧i va kriminologik zhix̧atlari (Criminal and criminological aspects of the fight against human trafficking), doctor's thesis, Tashkent: O'zR IIV Akademiyasi, 2016, 379 p.

24. Global Report on Trafficking in Persons 2018, Vienna: UNODC, 2018, $90 \mathrm{p}$. 
25. Global Slavery Index 2018, available at https://www.youtube.com/watch?v=CcJGsqCaaKo.

26. Laczko F., Marco A. Gramegna, Developing Better Indicators of Human Trafficking, The Brown Journal of World Affairs, 2003, vol. 10, No. 1, pp. 179-194.

27. Makonen G., Human Trafficking and Development: The Role of Microfinance, Transformation, 2006, vol. 23, No. 3, pp. 142-156.

28. Merriam-Webster, Coerce is to achieve by force or threat, available at https://www.merriam-webster.com/dictionary/coercing.

29. https://humantraffickinghotline.org/mission/.

30. Salazar R.P., Cecilia M.H., Ruth H.L., What Is Human Trafficking?, Sex: A Thematic Issue, The University of Chicago Press, 2012, vol. 37, No. 4, pp. 1015-1029.

31. Salett E., Nasr F., Glossary and definitions, Human Trafficking Search, 2017, 26 p.

32. The World Book Encyclopedia, volume 17, USA: World Book Inc., $446 \mathrm{p}$. 